Anetta Breczko, Alina Miruć

Uniwersytet w Bialymstoku

\title{
TOTALIZUJĄCE PRAKTYKI WE WSPÓKCZESNYCH DEMOKRACJACH (ASPEKTY FILOZOFICZNE I TEORETYCZNOPRAWNE)
}

\section{Wprowadzenie}

Nowoczesne technologie stały się obecnie kluczem do postępu cywilizacyjnego. Ich narzędzia wykorzystywane są we wszystkich niemal sferach działalności ludzkiej. Nieuniknioną konsekwencją rozwoju technologicznego stają się - zwłaszcza w dziedzinie technologii informacyjnej i biotechnologii - liczne zagrożenia. Wiążą się one z potencjalnymi naruszeniami godności ludzkiej oraz ograniczeniami wolności i prywatności jednostek. Konkretne wydarzenia z przełomu XX-XXI w. wskazują, że zasadne staje się ponowne rozpatrzenie pojęcia „totalitaryzm”, dotychczas przeciwstawianego demokracji. Okazuje się, że przeświadczenie o własnej wszechmocy i „monopolu na prawdę” odnośnie sposobów zapewnienia szczęścia obywatelom jest, niestety, cechą każdej władzy. Nie można nie zgodzić się z tezą Z. Baumana, że cywilizacja bez przymusu wydaje się właściwie nie do pomyślenia, a kontrola normatywna, związana nieuchronnie z ograniczeniem wolności indywidualnej stała się dziś faktem. ${ }^{1}$ Współczesne rządy ograniczają krępującą ich poczynania demokratyczną kontrolę, uzasadniając swoje decyzje polityczne i gospodarcze potrzebą zapewnienia bezpieczeństwa. ${ }^{2}$ Jak trafnie zauważył K. Pomian, w ,idealnych" wizjach świata, obecnych także u podstawy refleksji na temat państw demokratycznych, nadal pojawiają się więc „zatrute” ziarna, z których później, gdy są odpowiednio podlewane, a czasami i zmutowane (zwulgaryzowane), dojrzewa „totalitarny owoc". Współczesne technologie niewątpliwie temu sprzyjają. ${ }^{3}$ Czy rację

Z. Bauman, Szanse etyki w zglobalizowanym świecie, Kraków 2007, s. 30.

Ibidem, s. 312.

K. Pomian, Totalitaryzm, (w:) idem, Oblicza dwudziestego wieku. Szkice historyczno-polityczne, Lublin 2002, s. 53-78. 
ma zatem G. Agamben, który obawia się, że niebawem dojść może do upadku nowoczesnej demokracji i jej stopniowej konwergencji z państwami totalitarnymi? ${ }^{4}$ Problem ten stanowi leitmotiv rozważań czynionych w tym opracowaniu.

\section{Czym jest totalitaryzm?}

Przywykliśmy do uznawania za totalitaryzm jedynie takiego systemu opresji, w którym w relacjach społecznych dominuje strach. Tradycyjne totalitarne doktryny pierwszej połowy XX w. próbowały sterować ludźmi za pomocą lęków przed więzieniem, torturą i śmiercią. Totalitaryzm (od łac. totalis) odnoszony był do takich metod sprawowania władzy, które prowadziły do bezwzględnego podporządkowania jednostki. Państwa totalitarne uznawane za okrutne i represyjne, łatwo można było odróżnić od pozostałych, dzięki ogólnie przyjętym standardom praw człowieka. ${ }^{5} \mathrm{~W}$ dalszym ciągu uważa się, że metody totalitarne działania władzy prowadzą do całkowitej (zabsolutyzowanej) kontroli zewnętrznej. Kontrola ta możliwa jest dzięki stosowaniu punitywizmu. Uzasadnienie dla dyscyplinowania i karania wynika z absolutyzowania zbiorowości. ${ }^{6}$ Znakiem szczególnym doktryn totalitarnych jest pogarda dla wolności.

Pojęcie „totalitaryzm” klasycznie analizowane bywało w kategoriach przeciwieństwa do demokracji oraz liberalizmu. Jedną z najsłynniejszych prac, w której można odnaleźć definicję totalitaryzmu są Korzenie totalitaryzmu (The Origins of Totalitarianism) H. Arendt. ${ }^{7}$

Arendt wymienia trzy cechy systemów totalitarnych, które upodabniają je do totalitarnych ideologii. Należą do nich: 1) próba totalnego wyjaśniania nie tylko tego, co jest, ale także tego, co się staje, rodzi i przemija; 2) odporność na doświadczenie, które nie jest w stanie niczego skorygować i wzbogacić; 3) podporządkowanie „logiki doświadczenia” terrorowi „schematu pojęciowego”. Przekształcanie „zmyślonego świata” w rzeczywistość odbywa się dzięki polityce izolacji informacyjnej i ideologizacji całego życia. Umacnianiu totalitarnego porządku służą takie instytucje, jak: 1) administracja, która programuje działanie ruchu; 2) tajna policja, kontrolująca oddolne życie społeczne i uniemożliwiająca powstanie społeczeństwa obywatelskiego; 3) obozy koncentracyjne jako laboratoria dla przyszłego totalnego panowania nad światem. Kluczową cechą ideologii totalitarnej jest jej niepodatność na weryfikację i pogarda dla faktów. ${ }^{8}$

G. Agamben, Stan wyjątkowy. Homo sacer, Kraków 2008, s. 21.

Zob. K. Minoque, Co stanowi przeciwieństwo totalitaryzmu?, (w:) M. Kuniński (red.), Totalitaryzm a zachodnia tradycja, Kraków 2006.

W. Kaczyńska, W poszukiwaniu normatywnych i aksjologicznych podstaw etyki niesienia pomocy, (w:) W. Kaczyńska (red.), O etyce służb społecznych, Warszawa 2010, s. 316.

Zob. H. Arendt, Korzenie totalitaryzmu, Warszawa 2008.

K. Świrek, Trzy końce ideologii - najważniejsze dwudziestowieczne ujęcia problemu, „Nauka i Szkolnictwo Wyższe" 2013, nr 1/41, s. 44 i n. 
Obok opracowania H. Arend, fundamentalnym dziełem na temat totalitaryzmu jest również książka C.J. Fredricha The Unique Charakter of Totalitarian Society. Friedrich wyróżnia w niej pięć zasadniczych cech ustroju totalitarnego. Są nimi: 1) ideologia, w którą wszyscy mają wierzyć (skoncentrowana na obrazie doskonałego stanu ludzkości); 2) rządy monopartii kierowanej przez jednego człowieka; 3) pełna kontrola obywateli za pomocą biurokracji państwowej oraz partyjnych struktur; 4) niemal doskonała kontrola nad środkami i kanałami komunikacji; 5) system fizycznej i psychologicznej terrorystycznej kontroli policyjnej. Po 1956 r. doszło - pod wpływem współpracy ze Z. Brzezińskim - nowe kryterium: 6) centralna kontrola i kierowanie całej ekonomii. ${ }^{9}$

Krytycy teorii totalitarnych zaczęli z czasem poddawać w wątpliwość jakość demokracji zachodnich, wskazując na te ich właściwości, które upodobniają je do „systemów zniewolonych”. Zauważono, że demokracje liberalne wykazują liczne podobieństwa do systemów totalitarnych. Z perspektywy prawoznawstwa, szczególnego znaczenia nabrała typologia prawa przedstawiona przez P. Selznicka i P. Noneta, zgodnie z którą, obok modeli autonomicznych i responsywnych, można wyróżnić także model represyjny. W modelu tym prawo pełni rolę instrumentu sprawowania władzy. W pełni podporządkowane jest doraźnej polityce rządzących, sankcjonując oficjalną moralność. Uzasadnienie dla decyzji władczych, oparte zostaje na partykularnych korzyściach i interesach osób sprawujących władzę. ${ }^{10}$ Taki model prawa przejawia się dość często $\mathrm{w}$ praktyce działania władzy w państwach demokratycznych, zbliżając rzeczywiste rozwiązania do totalitarnej ideologii.

\section{Tendencje totalitarne w literackich wizjach przyszłości a rzeczywistość społeczna}

Wspomniani wyżej - H. Arend i C.J. Friedrich usiłowali uporać się z „demonami przeszłości”, poddając analizie realnie funkcjonujące reżimy totalitarne. Natomiast autorzy, tacy jak np. G. Orwell i A. Huxley, opracowali - mając na uwadze zastaną kondycję społeczeństwa - własne, prorocze wizje tego, co być może dopiero nastąpi. Stworzyli symboliczne obrazy przyszłej rzeczywistości i ostatecznego przeznaczenia świata, które wpłynęły na kształt dyskursu filozoficznego i prawniczego. Jak zauważa Z. Bauman, wizje te są w istocie bardzo podobne. Różne natomiast okazują się w nich drogi do tragicznej przyszłości oraz jej scenariusze: „obaj czuli głęboko, że tragedią ich świata jest uparte i niekontrolowane powiększanie się przepaści między coraz potężniejszymi i coraz bardziej odległymi kontrolerami, a coraz

9 Zob. C.J. Friedrich, Z.K. Brzeziński, Totalitarian Dictatorship and Autocracy, Cambridge 1965.

10 J. Srokosz, Komunitariańska wizja prawa responsywnego a koncepcja państwa prawa, (w:) M. Andruszkiewicz, A. Breczko, S. Oliwniak (red.), Filozoficzne i teoretyczne zagadnienia demokratycznego państwa prawa, Białystok 2015, s. 142. 
bardziej bezsilną i skrupulatnie kontrolowaną resztą." ${ }^{11}$ Niepokoiła ich perspektywa, w której ludzie pozbawieni zostają wpływu na własne życie; zaś ludzkie losy kreowane są przez zarządców, projektantów i nadzorców: „Nie potrafili wyobrazić sobie świata bez wież strażniczych i pulpitów kontrolnych. Ich ówczesne lęki, podobnie jak nadzieje i marzenia, krążyły wokół Biur Naczelnego Dowództwa". ${ }^{12}$

Nasuwa się nawiązanie do myśli M. Foucaulta, który posłużył się projektem Panopticonu, stworzonym pierwotnie przez J. Benthama. Foucault wykorzystał ów projekt jako metaforę nowoczesnej władzy. Pensjonariusze Panopticonu to osoby przywiązane do miejsca i pozbawione wszelkiej możliwości poruszania się; odgrodzone od świata grubymi, mocno strzeżonymi murami. Swoboda oraz pragmatyzm cechujący nadzorców zapewniają im dominację..$^{13}$

Wyobrażenie Panopticonu, zdaniem Z. Baumana, stanowi metaforę najważniejszych rysów unowocześnienia władzy i kontroli. Zniekształca nieco współczesne analizy socjologiczne, gdyż w nowoczesnych układach władzy szuka się starych - i w zasadzie niezmienionych technik panoptycznych - w nowej, usprawnionej wersji: „Często umyka naszej uwagi fakt, że większość naszej populacji, ani nie musi, ani nie ma okazji, by zaznać dawnych uroków placu musztry". ${ }^{14}$ Pojawiają się nowe techniki totalizujące, jakże wyraziste w czasach niewyobrażalnego postępu technologicznego.

Szczególne możliwości nadzorowania i kontroli jednostek przez władzę pojawiają się wraz z nowymi narzędziami, jakie dają technologie informacyjne. Wiele racji tkwi w przemyśleniach J. Oleńskiego, który zauważa, że w społeczeństwach informacyjnych następuje „koncentracja globalnych systemów informacyjnych w rękach niewielkiej grupy dysponentów, przy zachowaniu wszelkich form instytucjonalnych demokratycznego państwa. Dlatego rzeczywisty model polityczny, społeczny i gospodarczy kraju można poprawnie określić poprzez analizę i ocenę realizowanego w praktyce modelu informacyjnego danego państwa. Powszechnie uznane instytucje demokratycznego państwa i praworządności w warunkach wspó1czesnych technologii informacyjnych tracą swój rzeczywisty sens, stają się ,atrapami i parawanem" dla praktyk nie mających nic wspólnego z demokracją, jeżeli nie są wsparte właściwym modelem informacyjnym państwa." 15

Techniki totalizujące typowe są również dla tzw. „biowładzy”, stanowiąc bogate instrumentarium „,biopolityki”, która - zdaniem M. Foucaulta - narodziła się, gdy władza uświadomiła sobie, że ma do czynienia nie z poddanymi, nie z ludem, ale $\mathrm{z}$ populacją ze swoistymi dla niej zjawiskami: przyrostem naturalnym, zdrowiem, zachorowalnością, odżywianiem, warunkami mieszkaniowymi, etc. Człowie-

Z. Bauman, Płynna nowoczesność, Kraków 2006, s. 83.

Ibidem, s. 84

Ibidem, s. 17-20.

Z. Bauman, Globalizacja. I co z tego dla ludzi wynika, Warszawa 2000, s. 61.

J. Oleński, Model informacyjny państwa - implikacje dla polityki społecznej i ekonomicznej, (w:) A.F. Bocian (red.), Ekonomia-Polityka-Etyka, Białystok 2003, s. 59. 
kowi ofiarowana została techniczna i polityczna możliwość już nie tylko stwarzania i urządzania życia, ale także nieustannego kontrolowania go we wszystkich aspektach, istotnych dla przetrwania zbiorowości ${ }^{16} \mathrm{G}$. Agamben - nawiązując do przemyśleń Foucaulta - posłużył się obrazową, rzymską figurą homo sacer, człowieka wykluczonego ze społeczeństwa, którym może zostać każdy, o ile władza uzna, że dane życie nie jest warte ochrony prawnej i sprowadzi je do czysto biologicznego wymiaru. Agamben zauważył, że figura ta znajduje dziś swoje odzwierciedlenie w osobie muzułmanina - potencjalnego terrorysty. Krąg homines sacri jest zresztą otwarty. Mogą do niego trafić różne kategorie podmiotów, których funkcjonowanie zostanie uznane przez władzę za niepotrzebne, nieprzydatne lub $-\mathrm{z}$ jakichś względów - groźne. Cechą wspólną homines sacri jest to, że wszyscy oni pozostają w „stanie wykluczenia", gdyż zostali uznani przez władzę za niegodnych ochrony prawnej. Są „nagim życiem” w sferach „stanu wyjątkowego”. Podlegają przemocy, a prawo staje się w ich przypadku jedynie ,pustą formą". ${ }^{17}$ Agamben stworzył współczesną metaforę „stanu wyjątkowego" i „obozu” (camp/zone) w nowoczesnej przestrzeni politycznej. Ukazał zacieranie się (zarówno w teorii, jak i w praktyce społecznej) tradycyjnych rozróżnień „prawa” i „,bezprawia”. Zauważył, że współczesna władza działa w oparciu o reguły „stanu wyjątkowego”, który nakłada się na funkcjonujące w państwach demokratycznych systemy prawne. Odzwierciedleniem daleko idącej konwergencji systemów politycznych współczesnych państw demokratycznych i systemów totalitarnych jest właśnie istnienie obozów, rozumianych jako miejsca szczególne; wyodrębnione i zamknięte sfery, w których - w ramach wprowadzonego stanu wyjątkowego - umieszcza się współczesnych homines sacri. ${ }^{18}$ I chociaż można nie zgadzać się z twierdzeniem Agambena, że stan wyjątkowy upowszechnił się we współczesnych demokracjach jako model władzy, trudno odmówić słuszności opinii, iż nowoczesność różni się od poprzedzających ją epok tym, że „nagie życie”, kiedyś usytuowane na obrzeżach egzystencji politycznej, dziś coraz bardziej wnika w przestrzeń polityczną.

\section{O potrzebie redefinicji pojęcia „totalitaryzm”}

W XXI w. totalitaryzm przejawia się w wielu demokratycznych społeczeństwach jako nowoczesna forma tyranii i despotyzmu, możliwa dzięki nowoczesnym technologiom, prowadząca do coraz to bardziej skutecznej kontroli nad społeczeństwem przez rządzących.

\footnotetext{
16 M. Foucault, Wola wiedzy, (w:) idem, Historia seksualności, Warszawa 1995, s. 122.

17 S. Oliwniak, Giorgio Agamben: biopolityka i „pusta” forma prawa, (w:) W. Staśkiewicz, T. Stawecki (red.), Dyskrecjonalność w prawie: materiały XVIII Ogólnopolskiego Zjazdu Katedr Teorii i Filozofii Prawa, Międzeszyn k. Warszawy, 22-24 września 2008 r., Warszawa 2010, s. 540. 
Totalitaryzm nie musi obecnie przyjmować postaci znanej z praktyk nazizmu i komunizmu, czy wizji G. Orwella, opartych o powszechne terroryzowanie i inwigilację. Może to być także świat prorokowany przez A. Huxleya, w którym mechanizmem generującym trwałą atomizację społeczeństwa jest dostarczanie innych niż terror bodźców, doprowadzających w ostatecznym rezultacie do manipulacji, zniewolenia i deprawacji człowieka. Wystarczy przypomnieć amerykański film animowany z 2008 r. pt. Wall-e, wyreżyserowany przez A. Santona. W obrazie tym „obywatele przyszłości” mają fantastycznie zorganizowane, zautomatyzowane życie, niewymagające nawet ruszania się z wygodnych foteli. Doznają najrozmaitszych rozrywek. Ich egzystencja jest lekka, łatwa i przyjemna, głównie za sprawą postępu technologicznego, rzutującego nie tylko na sferę cielesności, ale także ducha. Jednak obraz ,nieprzerwanej przyjemności” kojarzy się nieuchronnie z totalitarnymi praktykami, kiedy to odgórne sterowanie możliwe jest za pomocą „,wyjałowienia świadomości”; podobnie jak ma to miejsce u Huxleya.

Totalitaryzm nie zawsze wiąże się więc ze stosowaniem przemocy fizycznej. Okazuje się, że „totalne zniewolenie” może być też skutkiem podstępnego kuszenia, zwodniczych obietnic, programowania neurolingwistycznego, etc. Człowiekiem można sterować nie tylko za pomocą przymusu i związanego z nim ,strachu przed karą", ale także obiecując mu przyjemności.

W społeczeństwach zachodnich XXI w. zaczęła się pojawiać nowa forma totalitaryzmu. Skupia się ona na deprawacji ludzkiego umysłu: „Wystarczy ludowi zaoferować odpowiednią dawkę panem et circenses - chleba i igrzysk, a nie będzie kwestionował użycia siły i decyzji władców”. ${ }^{19}$ Praca nad „wyjaławianiem świadomości" odbywa się za pomocą skomplikowanej machiny medialnej, która przedstawia świat w postaci „migawkowej”, dostosowanej do oczekiwań współczesnego odbiorcy, który - z założenia - nie powinien się przemęczać i przeciążać swojego umysłu. „Totalitarny umysł” staje się coraz powszechniejszy i coraz łatwiejszy do rozpoznania. ${ }^{20}$

Okazuje się, że elementy totalizujące widoczne są również w tym, jak wyspecjalizowani technicy (fachowcy) organizują świat społeczny. Sposób ich działania wyznaczony jest przez „kategorię ryzyka”. Nowoczesność, co zauważył A. Giddens - wprowadziła „całkiem nieznane wcześniejszym epokom parametry ryzyka. Są wśród nich rodzaje ryzyka na wielką skalę, wynikające z globalnego wymiaru systemów nowoczesności." 21 To właśnie w związku z tym - zdaniem niemieckiego socjologa U. Becka - we współczesnych „społeczeństwach ryzyka” sfera rzeczyw Krakowie 14 stycznia 2005 r., http://www.niedziela.pl/artykul/75990/nd/Plus-Ratio-quam-Vis (data dostępu: 8.10.2015 r.).

20 H. Hazlitt, Droga do totalitaryzmu, https://www.miasik.net/archive/2015/01/wstep-do-libertarianizmu/ (data dostępu: 8.10.2015 r.).

21 A. Giddens, Nowoczesność i tożsamość. „Ja” i społeczeństwo w epoce późnej nowoczesności, Warszawa 2002, s. 306 . 
wistego podejmowania decyzji znacznie się przemieściła. Nie jest nią już demokratyczna, publiczna debata polityczna, ale jej obszary zwane mianem „subpolityki”. Formy zaangażowania politycznego ,zlewają się w jeden ambiwalentny obraz, który nie da się ująć w stare kategorie przejrzystości politycznej”. ${ }^{22}$ Obszar polityczności przeniósł się do sfery korporacjonizmu, gdzie podejmuje się rzeczywiste decyzje. Newralgicznym obszarem subpolityki stał się przemysł. Podmiotami kształtującymi jej przyszłość są koncerny, prywatyzowane instytuty badawcze, lobby zbrojeniowe i największe mocarstwa. Tradycyjna polityka demokratyczna charakteryzuje się długą drogą realizacji, która jest uwieńczeniem debat, dyskusji, w wyniku których dokonywane są stosowne korekty. ${ }^{23} \mathrm{~W}$ obrębie subpolityki mamy do czynienia ze specyficzną natychmiastowością, bez uprzedniej legitymizacji decyzji. Subpolityka toczy się poza wszelką debatą publiczną, poza demokratyczną kontrolą - w nieprzejrzystych obszarach korporacji i przemysłu. ${ }^{24}$

Wydaje się, że najważniejsze tendencje totalizujące uwidaczniają się jednak poprzez ciągłe zwiększanie władzy rządu. Wiąże się to z tworzeniem coraz większej ilości regulacji dotyczących każdej sfery gospodarki oraz ograniczaniem wolności jednostki. Wraz ze wzrostem kontroli rządu wolna wola jednostki, czyli indywidualna kontrola nad własnymi sprawami we wszystkich sferach, jest coraz bardziej ograniczana. Zakres wolności i prywatności ulega stałemu pomniejszeniu. Dochodzi do jurydyzacji świata; jego kolonizacji poprzez coraz większą liczbę coraz bardziej szczegółowych norm prawnych. ${ }^{25}$ Obszary wolności kurczą się zatem. ${ }^{26}$ Inżynieria społeczna, typowa dla totalitaryzmu, staje się zaś coraz bardziej powszechna. Przejawia się w drobiazgowej regulacji prywatnych obszarów życia społecznego; często bez uwzględnienia uwarunkowań kulturowych oraz przy pomijaniu faktów i ,racji rozumu".

Zbliżanie się demokracji do totalitaryzmu jest również widoczne w dążeniach do coraz większej koncentracji władzy na szczeblu centralnym oraz coraz większej koncentracji władzy w rękach władzy wykonawczej (kosztem władzy ustawodawczej i sądowniczej). Ponadto, wielu autorów podkreśla, że proces wyborczy w demokracjach staje się właściwie fikcją; reklamową grą, maską realnej dominacji. To także zbliża te ustroje do totalitarnych porządków. ${ }^{27}$

Niewątpliwie, u podstawy wdrażanego przez rządzącą większość projektu leży ideologia, która nie zawsze oparta jest na racjonalnych przesłankach. Zauważyć należy, że współczesny totalitaryzm określany bywa coraz powszechniej jako pewna

22 U. Beck, A. Giddens, S. Lash, Modernizacja refleksyjna. Polityka, tradycja i estetyka w porządku nowoczesności, Warszawa 2009, s. 37.

23 P. Dybel, S. Wróbel, Granice polityczności. Od polityki emancypacji do polityki życia, Warszawa 2008, s. 65.

24 Ibidem, s. 69.

25 J. Habermas, Tendencje jurydyzacji, „Colloquia Communia” 1999, nr 1, s. 136.

26 M. Safjan, Granice autonomii człowieka w prawie współczesnym, (w:) E. Kamińska (red.), Uniwersyteckie wykłady na koniec starego i początek nowego tysiąclecia, Warszawa 2004, s. 214.

27 S. Wróbel, Biopolityka indywidualna a biopolityka państwowa, „Praktyka Teoretyczna” 2011, nr 2-3, s. $39-51$. 
forma ,irracjonalizmu”. ${ }^{28}$ To, co rozumne (reason) i to, co nierozumne (unreason) staje się podstawą do kontrastowych zestawien, istotnych przy klasyfikacji państw jako: „totalitarne”, „totalizujące” bądź „nietotalitarne”. ${ }^{29}$ Okazuje się, że u źródeł funkcjonowania wielu krajów, określanych dotąd jako „demokratyczne”, zauważyć można wielkie pokłady irracjonalizmu. Unereason widoczny jest szczególnie tam, gdzie w danym społeczeństwie przeważa światopogląd religijny.

W tym miejscu przypomnieć należałoby słowa R. Kapuścińskiego, który już wiele lat temu zauważył, że światu grożą trzy plagi. Pierwsza to plaga nacjonalizmu. Druga to plaga rasizmu. Trzecia zaś - religijnego fundamentalizmu. U ich podstaw leży wspólny mianownik. Jest nim agresywna, wszechwładna, totalna irracjonalność. Do umysłu porażonego którąkolwiek z tych plag nie sposób dotrzeć. Jest on bowiem zamknięty, jednowymiarowy i monotematyczny. Obraca się wokół jednego wątku - wroga..$^{30}$ Mowa nienawiści i podsycanie strachu przed obcymi widoczne są w Internecie. Ksenofobia - jako „ustawienie domyślne” człowieka - wydaje się tam powszechna. Problemem, w dość monolitycznym do niedawna społeczeństwie polskim, okazuje się fakt istnienia wielości kultur, wyznań, ras. Różnorodność bywa traktowana jako swoista prowokacja, wskutek której następuje niejako „zawieszenie” empatii wobec bliźniego, który okazuje się ,inny” niż my sami.

\section{Panopticon w cyberprzestrzeni, czyli o skutkach rozwoju technologii informacyjnych}

„Rewolucja informatyczna”, która rozpoczęła się w latach siedemdziesiątych XX w., zmieniła postrzeganie otaczającego nas świata. W ciągu ostatnich kilkunastu lat widoczny jest niezwykle dynamiczny rozwój technologii informacyjnych. W erze światłowodów i mikroprocesorów czas dostępu do informacji stał się cenniejszy niż pieniądze. Informacja i bazy danych zaczęły być narzędziem mocy i panowania. Czasy współczesne można więc określić mianem „ery informatyki”. Dzięki łączności satelitarnej możliwe jest dziś obserwowanie - w czasie rzeczywistym - zjawisk i wydarzeń w miejscach odległych o setki, a nawet tysiące kilometrów, zaś Internet stał się medium „totalnym”, które służy do masowej komunikacji na nieznaną dotąd skalę: „Środki techniczne, rozwijane konsekwentnie i bez przerwy, pozwoliły na przekazywanie informacji niezależnie od ich materialnych nośników, a także uwolniły ją od przedmiotów, których sama dotyczyła (...). Oddzielenie wędrówki samej informacji od ruchu jej nośników i przedmiotów pozwoliło z kolei zróżnicować ich prędkość. Informacja nabierała prędkości o wiele większej niż jej fizyczny nośnik i podróżowała szybciej, niż ulegała zmianie sytuacja, o której in-

Zob. K.R. Popper, Społeczeństwo otwarte i jego wrogowie, Warszawa 1993; R. Legutko, Spór o Platona, (w:) idem, Etyka absolutna i społeczeństwo otwarte, Kraków 1994, s. 73-95.

K. Minoque, Co stanowi..., op. cit.

Zob. R. Kapuściński, Imperium, Warszawa 1993. 
formowała. W końcu obsługiwana komputerowo sieć $w w w$ położyła kres samemu pojęciu ,podróż informacji” (a także odległości, na jaką ona wędruje), dostarczając danych, które teoretycznie i faktycznie dostępne są w tej samej chwili na całej planecie." ${ }^{11}$ Rozwój technologii informacyjnych oddziałuje na funkcjonowanie współczesnych społeczeństw, zauważalne relacje i podziały. Czas i przestrzeń obarczone zostały udziałem w tworzeniu i rozpadzie całości społeczno-kulturowych i politycznych. Zaczęły odgrywać znaczącą rolę w zachowaniu ich stabilności.

Informatyka stała się obecnie kluczem do rozwoju współczesnych państw i to we wszystkich właściwie sferach ich działalności, poczynając od polityki, administracji, przemysłu, handlu, edukacji, kultury, a kończąc na codziennym życiu każdej jednostki. Nowe, skomputeryzowane społeczeństwa, charakteryzujące się przygotowaniem i zdolnością do użytkowania systemów informatycznych, wykorzystujące usługi telekomunikacji do przesyłania oraz zdalnego przetwarzania informacji, określane są mianem ,społeczeństw informacyjnych” (ang. information society). Z powstawaniem tzw. ,republik elektronicznych” związane są wielkie nadzieje. Powszechna jest jednak także świadomość, że będą one generować wiele niespotykanych dotąd problemów i zagrożeń. ${ }^{32}$

Technologie informacyjne umożliwiają składowanie i przetwarzanie ogromnej ilości informacji. Jeśli dotyczą one prywatnych osób, nieunikniona jest kwestia prywatności. Pojawia się pytanie, jak portale społecznościowe mają się do jej ochrony? Można spotkać opinię, że twórca portalu Facebook.com. M. Zuckerberg, ,zarażając" swoim sposobem rozumienia prywatności pół miliarda użytkowników, praktycznie „zabił” prywatność, a przynajmniej zmienił jej rozumienie. Normą stało się uzewnętrznianie poglądów na wszelkie tematy. Użytkownicy tego portalu zrezygnowali właściwie ze swojej prywatności ujawniając milionom innych osób, firm i służbom specjalnym wiedzę o swoim wyglądzie, życiu, przekonaniach, upodobaniach, związkach emocjonalnych, stanie majątkowym, znajomościach, gustach, trybie życia, zdrowiu, etc. Sam Zuckerberg ogłosił, że prywatność przestała być normą społeczną.

Bazy danych budzą niepokój, który powoli zaczyna się przekształcać w problem wagi państwowej o charakterze globalnym. M. Poster porównał elektroniczną bazę danych do współczesnej wersji Panopticonu w cyberprzestrzeni. Zauważył, że nasze ciała są niejako ,zawieszone" pomiędzy sieciami, informacyjnymi magistralami i bazami danych. Można powiedzieć, że zostały „informatycznie przywiązane” do miejsc przechowywania informacji. Miejsca te nie stanowią już schronienia, w którym można się ukryć przed obserwacją. Przechowywanie ogromnej ilości danych, przyrastającej z każdym użyciem karty kredytowej, doprowadza - według Postera - do powstania Superpanopticonu. Jednak ten nowy Panopticon jest odmienny

31 Z. Bauman, Globalizacja..., op. cit., s. 20-21.

32 L.K. Grossman, Republika elektroniczna, (w:) Władza i społeczeństwo. Antologia tekstów z zakresu socjologii i polityki, Warszawa 1998, s. 265-294. 
od klasycznego. Nadzorowane w nim jednostki same dostarczają danych do przechowywania, stając się tym samym dobrowolnym czynnikiem w procesie kontroli. ${ }^{33}$

Z. Bauman podkreśla, że większość podobieństw między Panopticonem M. Faucaulta a współczesnymi bazami danych okazuje się powierzchowna. Panopticon stworzono przede wszystkim w celu wpajania dyscypliny i narzucania więźniom jednolitego sposobu zachowania. Działalność władzy była tam skierowana przeciwko różnicy, wyborowi i różnorodności: „Baza danych nie stawia podobnych celów ani sobie, ani swym potencjalnym zastosowaniom." ${ }^{34}$ Pierwotnie bazy danych zawierały dane o uczciwych i godnych zaufania klientach towarzystw kredytowych i firm marketingowych. Uniemożliwiało to wtargnięcie nieuczciwego konsumenta do owej ,przestrzeni pod nadzorem”. W klasycznym Panopticonie chodziło zaś o to, by nikt nie wymknął się spod kontroli. Ponadto, jak podkreśla M. Grozie, w tradycyjnej wersji Panopticonu wielu strażników obserwowało nielicznych więźniów, aby ewentualnie sankcjonować ich niesubordynację, albo zapobiec ucieczce z przestrzeni zamkniętej. W warunkach Superpanopticonu sytuacja ulega fundamentalnemu przekształceniu: nieliczni obserwują wielu, zaś przestrzeń jest otwarta. ${ }^{35}$ Tym niemniej strategia działania w ramach tych dwóch Panopticonów wydaje się dość podobna. Zmierza do tego, by pozostawić jak najwięcej swobody i możliwości manewru dominującemu oraz surowo ograniczyć swobodę podejmowania decyzji przez tego, kto dominacji podlega. ${ }^{36}$

W obu metaforach Panopticonu zauważalne jest manipulowanie informacją, polegające na jej wstrzymywaniu, zniekształcaniu i zatajaniu. Manipulacja taka zawsze odgrywała kluczową rolę w kontrolowaniu spraw ludzkich, czego przykładem jest cenzura stosowana w reżimach totalitarnych. Zdaniem L. Kołakowskiego: „Na większą lub mniejszą skalę wszystkie rządy okłamywały - wprost lub przez przemilczanie - swoich poddanych. Słusznie jednak można powiedzieć, że to nasze stulecie doświadczyło po raz pierwszy nowej cywilizacji, w której cały system władzy, to znaczy nadzór rządzących nad ludnością, opiera się na kontroli informacji. Ten, kto kontroluje wszystko, co wolno wiedzieć ludziom, jest bezsprzecznie panem. Nie musi się obawiać, że jego władza zostanie podkopana przez jakikolwiek zorganizowany ruch opozycyjny". ${ }^{37}$ Można skonstatować, że rodzaj mechanizmów, poprzez które informacja jest przekazywana i rozpowszechniana w społeczeństwie, w zasadniczy sposób określa funkcjonowanie tego społeczeństwa. Współczesne technologie informacyjne dają ogromne możliwości zarówno w zakresie inwigilacji, jak i nadzoru nad informacją.

M. Poster, Database as discourse,
nalization, Oxford 1996, s. 291 i n. 
Wskutek pojawienia się tzw. big date, czyli gigantycznych zbiorów danych zawierających wszelkie możliwe informacje dotyczące danej osoby, właściwie nie ma możliwości ogarnięcia tego, co się dzieje z naszymi danymi osobowymi. Staje się to tym bardziej niemożliwe, że rozpoczęła się era tzw. „Internetu rzeczy” (Internet of things). Na rynku pojawiają się naszpikowane nowoczesną technologią inteligentne domy, lodówki, samochody i ekspresy do kawy oraz różnego rodzaju osobiste urządzenia, komunikujące jednostkę ze światem (np. liczniki, przymocowane do ciała, wskazujące ile przebiegliśmy kilometrów, ile spaliliśmy przy tym kalorii i jakie było nasze tętno). Producenci oferują także np. „myślące” pieluszki oraz soczewki kontaktowe mierzące poziom cukru we krwi. U podstawy wszelkich tych urządzeń leży przekazywana firmom informacja. Należy pamiętać, że nad danymi, które przekazujemy do Internetu, tracimy na zawsze kontrolę. Nadzorujące państwo może korzystać z wiedzy o naszym profilu osobowym w celu jeszcze większego nadzoru.

Fakt, że firma lub rządy mają dane milionów ludzi prowadzi do radykalnych zmian w stosunkach władczych. W masowych programach inwigilacji, realizowanych przez amerykańskie i europejskie służby, nie chodzi tylko i wyłącznie o walkę z terroryzmem. Cyfrowe ślady generowane przez miliony użytkowników Internetu na całym świecie to doskonały materiał do politycznej analizy rzeczywistości i kontrolowania każdego, kogo państwo chce mieć pod kontrolą. ${ }^{38}$

W Stanach Zjednoczonych powstają różnego rodzaju projekty mające na celu powszechną inwigilację, która ma być dokonywana w celu zagwarantowania bezpieczeństwa. Zauważyć tam można bardzo wyraźnie wręcz modelowe tworzenie się ,,społeczeństwa pod nadzorem”. Jego symbolem stała się nie tylko zmilitaryzowana policja, przeszukująca lotniska i ulice miast oraz kamery śledzące obywateli. Głównym komponentem takiego społeczeństwa jest coraz bardziej powszechny proces tzw. „społecznego sortowania” w oparciu o rozmaite kody przetwarzane przez komputery.

Agencja Bezpieczeństwa Narodowego (NSA) prowadzi „Program Idealnego Obywatela" (Perfect Citizen), który monitoruje prywatne sieci komputerowe. Za jej sprawą Internet przekształcony został właściwie w „totalny system szpiegowski”. Możliwe stało się przeszukiwanie zawartości praktycznie każdego e-maila - i to bez nakazu sądu - który przychodzi do, lub wychodzi z kraju, pod kątem podejrzanych informacji. FBI działa by wprowadzić monitorowanie w czasie rzeczywistym poczty Gmail, Gogle Voice, Dropbox oraz usług ,w chmurze”. Rząd opracował dla US Air Force technologię nadzoru przeznaczoną do użycia przez służby porządkowe w celu monitorowania podejrzanych zachowań. Wykorzystane w niej zostały najnowsze osiągnięcia behawiometryki - technologii pozwalającej na odczytywanie myśli. Sensor buduje trójwymiarowy obraz twarzy obserwowanej osoby. Urządzenie może wychwycić unikalne ruchy mięśni i przetworzyć je w ,behawiometryczny profil”. 
The Cyber Intelligence Sparing and Protection Act (CISPA) to dokument, który daje służbom specjalnym swobodny dostęp do wszystkich elektronicznych danych bez zgody sądu. Poparły go firmy gromadzące informacje o internautach, w tym Microsoft czy Facebook, gdyż ustawa umożliwia im wolność korzystania z nich dla własnych potrzeb i ustanawia immunitet na procesy o naruszenie prywatności.

Także w większości państw europejskich wprowadzane są - w celu zagwarantowania bezpieczeństwa - specjalne programy inwigilujące obywateli. Przykładowo we Francji Sąd Najwyższy zatwierdził ostatnio kontrowersyjny projekt ustawy, który daje państwu duże uprawnienia. Służby krajowe uzyskały prawo do podsłuchiwania cyfrowej i komórkowej komunikacji każdego obywatela, podejrzanego o współpracę z terrorystami. Agencje wywiadowcze mogą instalować w prywatnych domach ukryte kamery i urządzenia rejestrujące. Mogą również umieszczać w komputerach tzw. keylogger - urządzenie, które rejestruje teksty pisane na klawiaturze w czasie rzeczywistym. Dostawcy usług elektronicznych są zobowiązani do instalowania tzw. „czarnych skrzynek” - złożonych algorytmów alarmujących władze o podejrzanych zachowaniach w Internecie.

Unia Europejska finansuje różne projekty umożliwiające nadzór nad cyberprzestrzenią. Należy do nich chociażby projekt HUMABIO, który będzie wykorzystywać biodynamiczne wskaźniki i analizę behawioralną do celów monitorowania ludzi. Kolejnym takim projektem jest SAMURAY, skupiający się na wykrywaniu podejrzanych i anormalnych zachowań za pomocą sieci kamer i sensorów. Podobnie, jeśli chodzi o projekt INDECT, gwarantujący automatyczne wykrywanie nieprawidłowości zachowań i zagrożeń w pomieszczeniach zatłoczonych. Finansowany przez Unię Europejską jest także projekt ADAPTS, pozwalający na przewidywanie zmian w zachowaniu. Wspomnieć należy, że w Europie rozpoczęty został proces budowania tzw. „Europejskiego Kompleksu Industrialnego Bezpieczeństwa” (NeoConOpticon the EU Security - Industrial Complex). Fundamentalnym jego założeniem staje się wykorzystanie biometryki, w której to dziedzinie Europa jest światowym liderem. Już od 2005 r. w Unii Europejskiej obowiązują przepisy dotyczące obowiązkowego pobierania odcisków palców od posiadaczy paszportów. W ramach wspomnianego procesu finansowany jest też projekt 3DFACE, za pomocą którego możliwe jest rozpoznawanie twarzy w technologii 3D.

Z praktykami totalitarnymi kojarzą się niewątpliwie działania rządów USA i Japonii dotyczące propozycji międzynarodowej umowy ACTA (Anti-Counterfeiting Trade Agrement).$^{39}$ Cel umowy, którym było ujednolicenie zasad ochrony własności intelektualnej poprzez zaostrzenie prawa, wywołał obawy, że może to ograniczyć wolność internautów. Próba stworzenia procedur śledzenia i permanentnej, legalnej inwigilacji internautów - pod pretekstem ochrony wartości intelektualnych - wywołała opór. Kontrowersje wzbudziła zasada domniemania winy każdego in- 
ternauty i przekładanie interesów korporacji ponad interesy obywateli. Niezadowolenie spowodował fakt, że rządy przygotowywały dokument tajnie, na wzór planów wojennych. Wykorzystały możliwości, jakie dają negocjacje międzynarodowe, nie podlegające kontroli obywatelskiej. Jedynym źródłem wiedzy o przygotowywanym dokumencie było Wikileaks. ${ }^{40}$

$\mathrm{Na}$ koniec wspomnieć należy, że funkcjonujące systemy monitoringu wizyjnego (prywatnego i publicznego) również pozwalają na totalną inwigilację (przynajmniej w miastach). Inteligentne programy analizują dane, rozpoznają twarze, ruchy, dźwięki i wyciągają wnioski. Mogą do tego też użyć danych z Internetu, przewidując, kto jest niebezpieczny. Na samym tylko Facebooku zarejestrowanych jest 450 milionów „twarzy”. Szczegółowa analiza nagrań z monitoringu w Polsce możliwa staje się dzięki wspomnianemu wcześniej unijnemu projektowi badawczemu INDECT, realizowanemu przez kilka polskich uczelni (np. AGH w Krakowie, Politechnikę Poznańską i Politechnikę Gdańską). ${ }^{41}$ Program ten wykorzystuje monitoring wizyjny, monitoring Internetu i monitoring komputerów. Najogólniej, wychwytuje on zachowania nietypowe i przemoc. Ma zapobiegać zagrożeniom dzięki ich automatycznemu rozpoznawaniu. W Polsce monitorowanych jest wiele miejsc. Wciąż jednak nie dorównujemy np. Wielkiej Brytanii, w której są 4 miliony kamer, zaś przeciętny Londyńczyk filmowany bywa 300 razy dziennie. Należy podkreślić, że polskie prawo właściwie nie reguluje monitoringu, z wyjątkiem uprawnień straży miejskiej i policji drogowej oraz przepisów dotyczących imprez masowych i kasyn. Dostęp do każdej istniejącej bazy mogą uzyskać: sąd, prokuratura, policja i służby specjalne. Sytuacja jest zatem analogiczna do ,bilingowania”, kiedy dane telekomunikacyjne mogą być pobrane nawet czysto prewencyjnie, a niekoniecznie w ramach prowadzonej sprawy karnej. ${ }^{42}$

\section{Represyjność współczesnych demokracji wobec „innych”}

Od pewnego czasu można zaobserwować celowe wytwarzanie sytuacji permanentnego „stanu wyjątkowego”. Stało się to jedną z podstawowych praktyk współczesnych państw, w tym także państw demokratycznych. Demokratyczna władza obawia się ,innych”; tych, którzy są przedstawicielami „mniejszościowych” kultur i religii, a także tych, którzy z jakichś innych względów oceniani są jako „nieprzystosowani" do życia w warunkach obywatelskiego społeczeństwa. Dotyczy to chociażby takich osób, które mogłyby być zagrożeniem dla bezpieczeństwa państwa (np. uchodźców i potencjalnych terrorystów). Obawy te uległy nasileniu, czy wręcz

M. Celiński, ACTA, czyli inwigilator, „Gazeta Wyborcza”, z dnia 24.01.2012 r., s. 17.

E. Siedlecka, Prywatności już nie będzie, „Gazeta Wyborcza”, z dnia 21-22.04.2012 r.

Rozmowa E. Siedleckiej z W. Wiewiórkowskim - Generalnym Inspektorem Ochrony Danych Osobowych, Wielkie Oko patrzy, „Gazeta Wyborcza”, z dnia 21-22.04.2012 r., s. 26-27. 
zmitologizowaniu, po zamachach na World Trade Center. W podsycaniu lęków znaczącą rolę odegrały niewątpliwie współczesne media.

Można spotkać opinie, że represyjny stosunek współczesnych państw do ,innego" jest w praktyce realizacją metaforycznej wizji „obozu”, stworzonej przez G. Agambena. ${ }^{43}$ Przedstawiona przez niego metafora „państwa jako obozu” zaczyna się powoli ziszczać. Współczesny obóz nie musi jednak przypominać Auschwitz; chociaż często rzeczywiście przypomina, tak jak chociażby obozy dla terrorystów (np. słynne więzienie Guantanamo). Współczesny camp/zona to obecnie również „obóz uchodźców”, czy „obóz tymczasowy” (Auffanglager). Ostatnio niemiecki Minister Spraw Wewnętrznych określił takim mianem statki uchodźców. Camp/zona to również jones d'attentes na międzynarodowych lotniskach.

Współczesny obóz jest zatem miejscem, w którym następuje czasowe „zawieszenie" statusu obywatela danego państwa. Obywatel zostaje w nim poddany kontroli służb lotniskowych, emigracyjnych, specjalnych. ${ }^{44} \mathrm{~W}$ ten sposób nowoczesny totalitaryzm prowadzi „wojnę domową”, w której istnieje fizyczna eliminacja nie tylko przeciwników politycznych, ale całych kategorii obywateli, których z jakichś przyczyn nie da się dopasować do określonego systemu prawnego. ${ }^{45}$ Problem ,zawieszenia" praw człowieka podejmowała - jeszcze przed Agambenem - wspomniana wcześniej H. Arend, która zauważyła, że: „Żaden z paradoksów współczesnej polityki nie kryje w sobie tyle gorzkiej ironii, co rozbieżność między wysiłkami idealistów o szlachetnych intencjach uparcie domagających się uznania za «niezbywalne» tych praw człowieka, które są udziałem jedynie obywateli w krajach o najwyższym poziomie dobrobytu i cywilizacji, a sytuacją ludzi tych praw pozbawionych". ${ }^{46}$

Agamben porównał działania podejmowane przez administrację G. Busha po ataku terrorystycznym z $2001 \mathrm{r}$. do Holokaustu. ${ }^{47}$ W tórowali mu także obrońcy praw człowieka, np.: N. Chomsky, A. Roy i M. Moore. Wyrazili oni podejrzenie, że administracja amerykańska po zamachach z 11 września świadomie podsycała konflikt, gdyż pod pozorem wszechobecnego zagrożenia ze strony islamu łatwiej przyszło jej przeforsować represyjną politykę wewnętrzną i zagraniczną, której od dłuższego czasu domagali się przedstawiciele neokonserwatywnej myśli politycznej. ${ }^{48}$

Wydaje się, że dobrym przykładem ukazującym represyjność współczesnych demokracji jest stosunek do uchodźców. Z aktów prawa pierwotnego Unii Europejskiej i Europejskiej Konwencji o Ochronie Praw i Wolności Człowieka wynika, że zasada poszanowania praw człowieka jest podstawową zasadą europejskiego i unijnego porządku prawnego. Jednocześnie wiele państw odrzuciło plan Komisji

Zob. G. Agamben, Homo sacer. Suwerenna władza i nagie życie, Kraków 2008.

S. Oliwniak, Giorgio Agamben..., op. cit., s. 109.

Ibidem, s. 107.

H. Arendt, Korzenie totalitaryzmu, Warszawa 1993, s. 335

K. Prokop, „Stan wyjątkowy” Giorgio Agambena a konstytucjonalnoprawna instytucja stanu nadzwyczajnego, (w:)

M. Andruszkiewicz, A. Breczko, S. Oliwniak (red.), Filozoficzne i teoretyczne..., op. cit., s. 393.

M. Schmidt-Salomon, Poza dobrem i złem, Słupsk 2013, s. 245-246. 
Europejskiej, która w maju 2015 r. ogłosiła decyzję o przyjęciu przez kraje Unii Europejskiej 40 tys. uchodźców. Najczęściej wymienianymi powodami sprzeciwu były rosnące obawy przed aktywizacją radykałów islamskich, którzy rekrutują kolejnych zwolenników wśród emigrantów. Wskazywano też na powody ekonomiczne i kulturowe. Prawa człowieka zostały więc ,zawieszone od odwołania” w stosunku do tych, których władza uznała za obcych i niezasługujących na przyznanie im ochrony prawnej. ${ }^{49}$ Ostatecznie władze unijne wprowadziły przymusowe rozdzielniki, co również może być oceniane jako przejaw totalizujących praktyk.

Narastający strach przed obcymi, islamistami, dżihadystami, uchodźcami z Afryki powoduje, że społeczeństwa demokratyczne domagają się prowadzenia polityki bezpieczeństwa kosztem praw człowieka. Opowiadają się za ochroną istnienia państwa narodowego, a nie urzeczywistnianiem społeczeństwa otwartego. Optują tym samym za demokracją ekskluzywną, a nie inkluzyjną. ${ }^{50}$

W epoce zagrożenia wojną nuklearną i wojną z terroryzmem, w obliczu światowej wojny domowej ,stan wyjątkowy” jawi się coraz częściej jako paradygmat władzy, dominujący we współczesnej polityce. ${ }^{51}$ Zauważalna jest tendencja do stałego i coraz bardziej nasilonego zaostrzania przez państwa europejskie swojej polityki w tym zakresie.

\section{Podsumowanie}

Rozwój technologiczny skutkuje wieloma zagrożeniami dla funkcjonowania demokratycznych społeczeństw. Wiążą się one głównie z potencjalną możliwością naruszenia godności ludzkiej, prawa do prywatności i wolności człowieka. Władza w państwach demokratycznych - dzięki nowym instrumentom technologicznym inwigiluje oraz nadzoruje także te obszary życia, które dotąd uznawane były za sferę prywatną. Zwiększająca się kontrola państwa skłania do tezy, że rozpoczął się proces stopniowej konwergencji ustrojów demokratycznych z państwami totalitarnymi, a praktyki totalizujące stają się wszechobecne w funkcjonowaniu współczesnych demokratycznych porządków.

\section{BIBLIOGRAFIA}

Agamben Giorgio. 2008. Homo sacer. Suwerenna władza i nagie życie. Kraków: Wydawnictwo Prószyński i S-ka.

Agamben Giorgio. 2009. Stan wyjątkowy. Homo sacer. Kraków: Wydawnictwo Ha!art.

\footnotetext{
49 S. Oliwniak, Giorgio Agamben o prawach człowieka we współczesnym demokratycznym państwie prawa, (w:) M. Andruszkiewicz, A. Breczko, S. Oliwniak (red.), Filozoficzne i teoretyczne..., op. cit., s. 101-103.

$50 \quad$ Ibidem, s. 112.

51 S. Agamben, Stan wyjątkowy. Homo sacer, Kraków 2008, s. 9.
} 
Arendt Hannah. 2008. Korzenie totalitaryzmu. Warszawa: Wydawnictwo Świat Książki.

Bauman Zygmunt. 2000. Globalizacja. I co z tego dla ludzi wynika. Warszawa: Wydawnictwo Państwowy Instytut Wydawniczy.

Bauman Zygmunt. 2006. Płynna nowoczesność. Kraków: Wydawnictwo Literackie.

Bauman Zygmunt. 2007. Szanse etyki w zglobalizowanym świecie. Kraków: Wydawnictwo Znak.

Beck Ulrich, Anthony Giddens, Scott Lash. 2009. Modernizacja refleksyjna. Polityka, tradycja i estetyka w porządku nowoczesności. Warszawa: Wydawnictwo Naukowe PWN.

Dybel Paweł, Szymon Wróbel. 2008. Granice polityczności. Od polityki emancypacji do polityki życia. Warszawa: Wydawnictwo Instytutu Filozofii i Socjologii PAN.

Foucault Michel. 1995. Wola wiedzy. W Historia seksualności, Warszawa: Czytelnik.

Friedrich Carl. J., Brzeziński Zbigniew K. 1965. Totalitarian Dictatorship and Autocracy. Cambridge.

Giddens Anthony. 2002. Nowoczesność i tożsamość. „Ja” i społeczeństwo w epoce późnej nowoczesności. Warszawa: Wydawnictwo Naukowe PWN.

Grossman Lawrence K. 1998. Republika elektroniczna. W Władza i społeczeństwo. Antologia tekstów z zakresu socjologii i polityki, s. 265-294. Warszawa: Wydawnictwo Naukowe Scholar.

Habermas Jürgen. 1999. „Tendencje jurydyzacji.” „Colloquia Communia” (1): 136.

Kaczyńska Wanda. 2010. W poszukiwaniu normatywnych i aksjologicznych podstaw etyki niesienia pomocy. W O etyce służb społecznych, s. 316, Warszawa: Wydawnictwo Instytutu Profilaktyki Społecznej i Resocjalizacji UW.

Kapuściński Ryszard. 1993. Imperium. Warszawa: Wydawnictwo Czytelnik.

Kołakowski Leszek. 2014. Niepewność epoki demokracji. Kraków: Wydawnictwo Znak.

Legutko Ryszard. 1994. Spór o Platona. W Etyka absolutna i społeczeństwo otwarte, Kraków: Wydawnictwo Arcana.

Lemke Thomas. 2010. Biopolityka. Warszawa: Wydawnictwo Instytutu Filozofii i Socjologii PAN.

Mathiensen Thomas. 1997. „The viewer society: Michel Foucault's „Panopticon” revisited.” Theorethical Criminology" vol. 1. (2): s. 215-234.

Minoque Kenneth. 2006. Co stanowi przeciwieństwo totalitaryzmu? W Totalitaryzm a zachodnia tradycja. Kraków: Wydawnictwo Ośrodek Myśli Politycznej i Księgarnia Akademicka.

Oleński Józef. 2003 Model informacyjny państwa - implikacje dla polityki społecznej i ekonomicznej. W Ekonomia-Polityka-Etyka, s. 59. Białystok: Wydawnictwo Uniwersytetu w Białymstoku.

Oliwniak Sławomir. 2010. Giorgio Agamben: biopolityka i „pusta” forma prawa, W Dyskrecjonalność w prawie; materiały XVIII Ogólnopolskiego Zjazdu Katedr Teorii i Filozofii Prawa, Międzeszyn k. Warszawy, 22-24 września 2008 r., s. 540. Warszawa: Wydawnictwo LexisNexis.

Oliwniak Sławomir. 2015. Giorgio Agamben o prawach człowieka we współczesnym demokratycznym państwie prawa. W. Filozoficzne i teoretyczne zagadnienia demokratycznego państwa prawa, s. 101-112. Białystok: Wydawnictwo Temida 2.

Pomian Krzysztof. 2002. Totalitaryzm. W Oblicza dwudziestego wieku. Szkice historyczno-polityczne, s. 53-78 Lublin: Wydawnictwo UMCS. 
Popper Karl. R. 1993. Społeczeństwo otwarte i jego wrogowie. Warszawa: Wydawnictwo Naukowe PWN.

Poster Mark. 1996. Database as discourse, or electronic interpellations. W Detraditionalization, s. 291 i n. Blackwell Publishers Ltd. Oxford.

Prokop Krzysztof. „Stan wyjątkowy” Giorgio Agambena a konstytucjonalnoprawna instytucja stanu nadzwyczajnego. W Filozoficzne i teoretyczne zagadnienia demokratycznego państwa prawa, s. 393. Białystok: Wydawnictwo Temida 2.

Safjan Marek. 2004. Granice autonomii człowieka w prawie współczesnym. W Uniwersyteckie wykłady na koniec starego i początek nowego tysiąclecia, s. 214. Warszawa: Wydawnictwo Uniwersytetu Warszawskiego.

Srokosz Jacek. 2015. Komunitariańska wizja prawa responsywnego a koncepcja państwa prawa. W Filozoficzne i teoretyczne zagadnienia demokratycznego państwa prawa, s. 142. Białystok: Wydawnictwo Temida 2.

Schmidt-Salomon Michael. 2013. Poza dobrem i złem. Słupsk: Wydawnictwo Dobra Literatura.

Świrek Krzysztof. 2013. „Trzy końce ideologii - najważniejsze dwudziestowieczne ujęcia problemu.” Nauka i Szkolnictwo Wyższe 1(41): s. 44 i n.

Wróbel Szymon. 2011. „Biopolityka indywidualna a biopolityka państwowa.” Praktyka Teoretyczna (2-3): s. 39-51. 
TOTALIZING PRACTICES IN MODERN DEMOCRACIES

(PHILOSOPHICAL AND THEORETICAL-LAW ASPECTS)

In the present paper, we focus on diverse threats to the functioning of democraticsocieties, associated with technological progress. Information technologies can lead to the violation of human dignity and contribute to the transgression of human rights and freedoms. Authorities in democratic countries thanks to new technological instruments - control and supervise areas of life that hitherto were considered private. This increasing state control leads us to the thesis that there is an incipient process of gradual convergence between democratic and totalitarian countries, and that totalizing practices become more and more pervasive in the functioning of modern democratic systems.

Keywords: security, privacy, authority, supervision, surveillance, information technologies

Słowa kluczowe: bezpieczeństwo, prywatność, autorytet, nadzór, inwigilacja, technologie informacyjne 